\title{
Picture Perfect: Anne Sexton's “The Double Image" Reflects the Poet as Daughter, Mother, and Anorectic
}

\author{
Jessica Mehta (Corresponding author) \\ University of Exeter, United Kingdom \\ Email: jt587@exeter.ac.uk \\ ORCID: https://orcid.org/0000-0003-4954-3121
}

Received: 27/04/2020

Accepted: 16/06/2020

Published: 01/07/2020

Volume: 1 Issue: 2

How to cite this paper: Mehta, J. (2020). Picture Perfect: Anne Sexton's "The Double Image" Reflects the Poet as Daughter, Mother, and Anorectic. Journal of Critical Studies in Language and Literature, 1(2), 26-36

DOI: https://doi.org/10.46809/jcsll.v1i2.8

Copyright ( 2020 by author(s) and Global Talent Academy Ltd. This work is licensed under the Creative Commons Attribution International License (CC BY 4.0).

http://creativecommons.org/licenses/by/4.0/

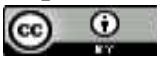

\begin{abstract}
Anne Sexton's poem "The Double Image" is explored, delving into the complexities of the role of the author as confessional poet, daughter, mother, and anorectic. This piece begins by noting the differences between the final published piece and the earlier drafts of the poem, focusing on the subtle differences and attempting to decipher why these changes were made. The significance of Sexton's childhood home in the poem is noted, as this is seen to infantilise the author and creates a narcissistic regression often seen in anorectic patients. Sexton's recurrent mouth imagery is addressed, as it is the gateway for food (or lack thereof) and plays a crucial role in the works of Sexton throughout her work and life. This topic is further developed into using hunger and eating metaphorically by Sexton, noting that as a daughter she engulfed everything in her mother's world. The placement of the portraits in the poem is another aspect that Sexton changes consistently throughout the drafts and this piece delves into theories of the significance the position of the portraits might have had. This piece ends with the importance the color green has for the author in her work, possibly linking it to the choice of using green for the wicked within the original technicolor version of The Wizard of Oz (LeRoy \& Fleming, 1939).
\end{abstract}

Keywords: Anorexia, Confessional Poetry, Anne Sexton, “The Double Image,” Eating Disorder, Poetry

\section{Introduction}

This research began with what appeared to be a simple question: Why do so many female poets seem to have an eating disorder (ED)? It was, of course, in actuality a very complicated question. Neither poetry nor eating disorders are simple. They are full of subtleties, multiple facets, and perspectives shaped by lives, cultures, languages, and genetics unique to each person. Anorexia nervosa (anorexia) was not technically named as such until 1873 by British physician William Whitney Gull (1873, p. 498). It is one of the deadliest of all mental disorders and notoriously under-diagnosed (Raineri, 2014, ii). Anorexia is an enigma of a disorder in many ways, but one that presents itself uniquely within the writing of poets like Anne Sexton in what Alexandra Rigl has termed the "anorexic aesthetic" (2014, p. 4). This aesthetic connects disease to art and can include (but is not limited to): neurosis embodied in writing; renunciation themes and images; dualism; odd punctuation; the narrative "I" occupying a liminal space; and art as a pattern of self-sabotage. This paper considers a single poem of Sexton's, "The Double Image" (1959, 1960), through the lens of Sexton's possible-and what I consider very likely-anorexia. 
"You told me I hadn't found my voice," Anne Sexton wrote to W.D. Snodgrass in November 1958 (Sexton, 1977). "But this poem has a voice." She was referring to her draft of "The Double Image" and went on to explain almost apologetically that the poem's voice was both changing and lame, "but [a] real voice, I think ... whether or not it is my best voice, I am not sure" (39). Snodgrass replied on 30 December 1958, applauding Sexton for not drifting from her craft; in a subsequent letter a fortnight later on 13 January 1959, he urged her, "Be yourself” (HRC 25.7).

The full details of these letters somewhat contradict Steven Colburn's statement that Sexton had hailed "The Double Image" as "the first poem in which she had truly found her voice as a writer" (Colburn, 1989, p.20). In actuality, Sexton first attributed the voice in question to the poem, not herself, and was quick to stress that the voice was unfixed and evolving. When she did lay partial claim to the voice as being hers, she inferred that it was one of many-and maybe not her best. The idea of a "double" (or even multiples) within female writers and anorectics has been well explored, quite notably in The Madwoman in the Attic (1979) and Hilde Bruch's landmark Eating Disorders. Sexton tackled such a notion head-on in this early poem, which was initially rejected by both The Hudson Review and The New Yorker in the spring of 1958. She resubmitted it to Frederick Morgan, The Hudson Review's editor, on 11 December 1958 just two weeks after writing to Snodgrass. It was accepted three weeks later.

\section{Early Evolutions of "The Double Image"}

The Harry Ransom Center (HRC), The University of Texas at Austin holds various Sexton archives comprised of extensive poem drafts, including one draft of "The Double Image." It is surely one of several given Sexton's habit of redrafting (and the fact that it was workshopped in Robert Lowell's course), but it remains the sole remaining draft of "The Double Image" held at the HRC. It differs significantly from both the version in The Hudson Review and the collected version in Sexton's To Bedlam and Part Way Back (1960). Consider the full draft held at the HRC:

Two portraits hang on matching opposing walls; each stares

At the other who watches her. as if they were petrified

Upon the air. Both ladies are sitting in umber chairs.

They wait in time. One still lives. The other has died.

I.

Part way back from bedlam I had come

To cradle in my mother's house, to wring

That madness out of me, my first death undone.

I ate her summer into me and turned to swing

Into my father's arm. But my portrait, how thin

I was then; only the smile is slipping into place.

The shadow greens my bone, but only this gold in

The skin shapes me alive. The frozen eyes of my face

Disguise nothing. What could I have been thinking there,

To let them paint my sickness out? Perhaps I didn’t care.

My father has placed us here. Each day I must meet My mother crossing me, going somehow her other way. These portraits such my living vein. I dream they speak, Twisting the stale air. I fear that I will betray Our double image, as I rustle past them, never alone.

She eyes me from the stony head of death I had outgrown.

II.

Part way back from cancer she had come That next wintertime. She stayed to wring Her living out; her body pulsing in, slowly undone, Moving past my naked arm. She turned to swing Away from me; her bright plum cheek growing thin, Wilting like a dry orchid. The smile is out of place. Why did she pose for this while death was eating in Her skin? I don't know. I watch the moment in her face And wonder, each twist of the brush and dying there.

She let them paint her living out. Maybe she didn't care. 
The hours come tandem in this room; I am forced to meet

Her face crossing mine, moving always her other way.

We mock each other, wall to wall. Will I never speak

This horror out, here in this room, will I never betray

The fiction that green is gold, that plum is orchid? Never alone,

I breathe my nights and trouble in this bed to which I've grown.

\section{(HRC Box 41.1)}

The draft includes just two parts and five stanzas in total with a handwritten note by Sexton at the top that reads, "not out- / to be rewritten / soon" (HRC Box 41.1). Both published versions include seven parts and 24 stanzas. It is impossible to directly compare this draft to published versions due to such ample differences, but some key decisions by Sexton should be examined.

The draft shows Sexton's indecisiveness when describing the placements of two portraits as either on matching or opposite walls. She scratches out the initial typed "matching" in pencil and replaces it with the handwritten "opposite." The portraits she describes are of her mother, Mary Gray Staples, and herself. She struggles to define geographically where she (by way of her portrait) is in relation to her mother, ultimately rejecting "matching" locations for "opposite" walls in this draft and both published forms, effectively distancing herself from her perceived "double." Unlike the draft which tells where the portraits are in the first line, the published versions do not reveal the placements until part 5 (Sexton, 1960). Sexton also shifts the focus from the portraits (and, in turn, on her and her mother) in the draft's first stanza to address her youngest daughter, Joyce Sexton, in the published versions. By delaying the naming of the portrait placements in published versions and addressing her daughter directly as "you," Sexton solidifies the poem's focus from one mother-daughter relationship (herself and her mother) to another (herself and her daughter). We will see that this merging of generations is a key aspect of the poem's published versions and its various criticisms.

It is not the poem's speaker (Sexton) who chooses the portrait placement in the draft, but her father, Ralph Churchill Harvey: "My father has placed us here" (HRC Box 41.1). This resignation and redirection of power in the draft shifts responsibility and control away from the adult poet who is forced to return to her familial home post-hospitalisation and back into the hands of her parents, infantilising Sexton. Simultaneously, the father dictating where the portraits are placed or physically hanging them himself reflects the patriarchal structure of the era and Sexton's family dynamics, highlighting what Jo Gill has called the "social and gender conformity which characterize suburban domestic life at this time" (Gil, 2007, p.60). The published versions of the poem void the father entirely, but maintain that the house belongs to Sexton's mother and not her parents. This cutting out of the father allowed Sexton to somewhat escape his control (if not her mother's), which is crucial considering it was her father who was so strict when it came to his daughters' appearances. Sexton and her sisters were forced to perform on command for guests, get their hair styled weekly, and according to her eldest daughter Linda Sexton, "Mother could never forget how her father had banned her from the dinner room table because he could not bear to look at the pimples of her adolescence" (Sexton, 1994, p.38). However, when it came to her mother, there is no such escape.

\section{Anne Sexton's Maternal Home}

Sexton emphasises her regression in the draft when she describes her return home as an intent "to cradle" (specifically in her mother's house) creating tensions regarding whose house it is and who has control (HRC Box 41.4). Bachelard (2014) described childhood homes as capable of keeping its young inhabitants children forever, claiming "the house is a large cradle ... and the poet well knows that the house holds childhood motionless in its arms" (p. 29). Sexton's atavism in the poem is echoed in Linda Sexton's recollections, who revealed that, "At nine I was required to be the mother because my own mother had descended once again into childlike behavior" (Sexton, 1994, p.65). Sexton's daughter described in her memoir that as a child she was forced to "play nine," a game where her mother would cuddle her and demand, "Now you be the Mommy ... and I'm your little girl" (Sexton, 1994, p.63). Sexton's choice of using the active verb "to cradle" instead of the more expected "to be cradled" may be an attempt - even while feeling regressed to an infantile state-to claim autonomy. If a cradling will occur, taking an active stance through language is a grab for power. However, in the end, Sexton removed the cradling reference in published versions. A similar grasping for control can be seen in part 2 of the published versions, with each of the four stanzas ending in various iterations of who exactly had Sexton's portrait "done." The commissioner was not necessarily, as some critics have assumed, her mother. Sexton pointed to three possible sources: "I had my portrait / done instead," "She [Mother] had my portrait / done instead," "I had my portrait / done instead" is repeated, and finally "They had my portrait / done instead" (Sexton, 1960, p.55). It is clear Sexton was struggling with who to name as portrait commissioner, and although the poem's speaker claimed command twice, ultimately an unnamed "they" wrangled authority over the portraits leaving the speaker in the role of passive child.

Reverting to a dependent childlike state is quite common in anorectics. Sexton was aware of the unnatural regression in the published versions of the poem when she called herself an "outgrown child" and realised that it is "Too late / too late, to live with your mother" (Sexton, 1960, p.53). Such self-awareness is not present in the poem's draft. One case study reported by Meyer and Weinroth (1957), around the time that Sexton was working on "The Double Image," described the backsliding 
of a 31-year-old anorectic woman to such a severe state of babyhood it was termed "narcissistic regression" (p.391). Hedley (2000) has pointed to a similar degree of narcissism in the published versions of "The Double Image," calling the poem a "confession of maternal narcissism" (p.87). Sexton has had many critics label her as narcissistic and Ostriker (1998) claimed, "Critics get in line for the pleasure of filing her under $\mathrm{N}$ for Narcissist" (p.59). Williamson (1983) called her "the uneasy narcissist, self-indulgent and sarcastic" (p.178). However, the term narcissism, particularly for a poet, may sometimes carry unwarranted negative connotations. Gill (2007) attributed Sexton's so-called narcissism as a "self-absorption of her writing," not herself, or a type of "textual narcissism" (p. 35). One must only look to the root story of Narcissus to see how such a "textual narcissism" presents itself in "The Double Image." Echo retreated to a cave when her love for Narcissus was unrequited, while he fell into a pool to his death-literally drowning in self-adoration and his mirror image. Sexton's lines "A cave of a mirror," and "this was the cave of the mirror" in published versions of "The Double Image" suggests that not only was she well aware of the narcissism (or perhaps Narcissist) embedded in the poem, but she reveled in it and by no means tried to hide it (Sexton, 1960, p. 57, 60).

\section{The Mother-Daughter Bond}

Sexton may have freed herself of her father from draft to publication stage, but by way of the portrait placements the poem's speaker remained indefinitely forced to stare, petrified, at her mother. She was fated to spend eternity gazing at her self-described double in a sort of prison — or cage. Sexton eventually came to see some types of imprisonments as comforting in later years, but only when she got to decide what (or who) was put inside. While lecturing at Colgate University as the Crawshaw Chair in Literature (1971-1972) toward the end of her life, in a series of addresses titled "Anne on Anne," she described tight lyric forms as a welcoming cage where poets could put wild animals in order to "make a logic out of suffering" (Holdstein \& Bleich, 2001, p. 102). These wild animals might be seen as metaphorical senses of self, the animalistic and wild parts of us that require taming. According to her lecture notes held at HRC, "All writing of poems is sanity, because one makes a reality, a sane world, out of insane happenings" (Holdstein \& Bleich, 2001, p. 102). Through her drafts and various poem versions, we can watch her configure some semblance of a "sane world" out of an inarguably chaotic life. The draft of "The Double Image" opens with a stanza that precedes episodic numbered parts, whereas all published versions delve straight into parts 1-7 (mirroring the seven rooms of Sexton's familial home described in published versions). Sexton dismantled and re-distributed much of the draft's opening stanza into the published versions where it can be found woven into parts 5 and 6 . In draft form, she makes it clear that the portraits are of two different "ladies," but the lines between Sexton and her mother begin to dissolve by the time the poem is published. Both the version in The Hudson Review and To Bedlam and Part Way Back embellished upon the language in the draft's first stanza to meld "both ladies" into one. Consider the opening stanza in the draft followed by the lines in part 6 of both published versions below:

Two portraits hang on matching opposite walls; each stares

At the other who watches her, as if they were petrified

Upon the air. Both ladies are sitting in umber chairs.

They wait in time. One still lives. The other has died.

(HRC Box 41.1)

that double woman who stares

at herself, as if she were petrified

in time - two ladies sitting in umber chairs.

You kissed your grandmother

and she cried.

(Sexton, 1960, p.53)

The published versions fluidly and rapidly shift between that of a singular woman, "that double woman who stares / at herself," and "two ladies," accentuating the notion that the poem's speaker genuinely encompassed a merging or duality. The voice becomes effectively split by the time the poem is published. The description of "petrification," which of course can mean both fear and turning into a stone-like state, shifts from "they" to a singular "she." The poem's draft struggles to focus on either the singular speaker or the mother, leaving Sexton's daughter out entirely-toddler Joyce does not make an appearance until the poem's publications. Sexton stressed a matriarchal, inter-generational lineage in published versions by naming her own mother as "grandmother" and sealing the relationship between the two with a kiss.

\section{The Mouth in "The Double Image"}

Although the kiss between grandmother and granddaughter in "The Double Image" is not detailed and not overtly inferred to be inappropriate, one must wonder at the reason for the grandmother's tears and cannot help but consider Sexton's own purported history with incestual kissing and sexual assault. Linda Sexton described her mother as "the bad thing-on top of me" in her memoir (Sexton, 1994, p. 276). "Her tongue-it's in my mouth. Wet and slimy. She's putting the poison 
down deep inside," Linda Sexton recalled to her therapist (Sexton, 1994, p. 276). Sexton was also preoccupied with kissing and the tongue throughout her oeuvre, including in the poem "Is it True?" (1975) where the speaker states "My tongue is slit. / I cannot eat" and makes repeated references to original sin (Sexton, 1971, 48). "The White Snake" is one of the more obscure fairy tale cum poems she included in Transformations and includes the lines "Their bodies met over such a dish. His tongue lay in her mouth / as delicately as the white snake" (Sexton, 1971, 48). Beaumont (2016) claimed that the story of "The White Snake" attracted Sexton because of its focus on eating as a "plot-starter," backing up Diane Middlebrook's assertion that eating was a primary symbol in the poem (p. 232). In both poems, the tongue is aligned with a snake-the serpent of Eden and pusher of knowledge. We have already seen the strong ties between Eve as the original disorderly eater and EDs, so it is no surprise that Beaumont also makes this connection. However, Beaumont exclusively links the outbreak of a "cold sweat" in "The White Snake" to anxiety, seeming to miss the fact that cold sweats are also a very common side effect of an ED". Regardless of this unfortunate oversight, it is clear that for Sexton "kissing" might be used (and abused) in a number of ways, including as a means of coalescence. In a letter from Sexton to Linda Sexton dated 23 July 1969, she declared with a tinge of warning, "For better or worse you inherit me" (Sexton, 1977, p. 308). These words complement the last words of the published version of "The Double Image" that were addressed to Joyce Sexton: "I made you to find me" (Sexton, 1960, p.61). Sexton wrote in her unpublished lecture notes of that famous last line, "Sounds nice, doesn't it? Poetic. That I should write such a poem and get my daughter" (HRC Crawshaw pp. 172). Ultimately, she revealed in these notes such a tidy ending was untrue.

Such a fusion between mother and daughter (or grandmother and granddaughter in some instances) is a recurring theme in Sexton's work, like in her short narrative "Dancing the Jig". This story features a speaker at a cocktail party-an adult Sexton - who hopes she gets mistaken for drunk when she cannot help but revert to a childlike state. She is pulled into a memory of a family meal around the dinner table where the hypnotic rhythm of her mother's mouth is intoxicating. Family mealtimes were anxiety-inducing for the young Sexton, and she was notorious for eating either in her bedroom or in the breakfast room away from her parents until she was eleven years old (Middlebrook, 1991, p.9). Middlebrook (1991) identifies the scene in "Dancing a Jig" as an example of Sexton's fascination with her mother's mouth. Gill has called the tongue (and other body parts and functions) in Sexton's "Letters to Dr. Y." (1960-1970) a metaphor and metonym for poem writing, and the mouth in some of Sexton's other poems a metonym for speaking a poem aloud (Gill, 2007, p.25, 150). What, then, are the implications of a young Sexton struggling to keep up with the multiple mouth functions required of her at a family dinner to the point of utter confusion? Sexton's "Dancing a Jig" describes the speaker's mother who "keeps up a steady stream of criticism while the daughter [Sexton] tries to chew, talk, and hold her own. The daughter cannot unconfuse their mouths" (Middlebrook, 1991, p.9). If the mouth and tongue are both necessary hubs for nourishment (and, contrarily, EDs) as well as metaphors for creating poetry, such a dinner-time struggle implies grave consequences for Sexton, ranging from starvation to writer's block. Memories like this are probably why Linda Sexton wondered, as a child, "Why is mealtime always so difficult ... why does it loom like a black pit at the end of every day?" (Sexton, 1994, p. 54). Between the draft and published versions of "The Double Image," Sexton did manage to achieve some dominance when it came to meals with "Mother."

The draft of the poem wonders of Sexton's mother, "Why did she pose for this while death was eating in / her skin?" (HRC Box 41.1). Like every word in the poem, "pose” was carefully selected and one of Sexton's talents. Arthur Furst wrote, "Anne was provocative and sexy, using all of her posting skills from her days as a model" (ix). Maxine Kumin called Sexton "every inch the fashion model" well after Sexton's modeling stint at Boston's Hart agency (Sexton, 1991, p.19). According to Dorfman (1981), the photographer who shot Sexton for Fiction magazine in 1974, the poet "knew how to respond to a camera" (p.2). Posing can be physically or behaviourally based and is inherently rooted in inauthenticity or fakeness. Ossip (2016) posits, "Fakeness is part of Anne Sexton's poetic myth" (p.192). Fakeness was even celebrated in a 1966 documentary on Sexton where she and her daughters are directed to pose. In between takes, the camera catches Sexton demanding of her eldest daughter, "Tell them we're fake!" (Ossip, 2016, p.183). The hungry death that eats Sexton's posing mother in "The Double Image" is a bit humanised by the eating reference, but still impersonal and operating as a disease does; Sexton has nothing to do with her mother's cancer in the poem's draft. However, the published versions equipped Sexton with full responsibility for the consumption. Here, it is claimed that it was Sexton's anthropomorphic attempted death (and, by extension, Sexton herself since suicide is self-directed) that consumed her mother: "as if my dying had eaten inside of her" (Sexton, 1960, p. 56). The "my" makes all the difference. Sexton worked to further trivialise her mother in the published versions via the description of her mother's portrait:

my mocking mirror, my overthrown

love, my first image. She eyes me from that face,

that stony head of death

I had outgrown.

$$
\text { (Sexton, 1960, p. 60). }
$$

That "first image" is also a false image ("mocking mirror") which Sexton had outgrown. This is representative of the end stage of the Lacanian infantile mirror-gazing with realisation complete. Narcissism, textual or otherwise, has come to mean 
many things and present itself in a variety of ways. Lacan (1977) likened narcissism to an infant's initial understanding of identity, calling this "le stade du miroir" (the mirror stage) of life (p. 2).

\section{Hunger as Portrayed in Sexton's Works}

Both "Dancing the Jig" and the various details we have explored in "The Double Image" reflect Melanie Klein's theory of introjection, or the child's unconscious adoption of the habits and ideas of others. Klein found that instances of a child's introjection as a form of defence against anxiety usually occurred prior to a regression, often with the child's introjection of the mother via "ideal loved and loving breasts" (Segal, 2018, p.17). Mother's milk is, of course, usually the first source of nourishment, and the breast the first source of that nourishment. The dynamic of nursing creates a complete dependency on the child to her mother - and potentially creates the ideal foundation to develop an ED from birth should the feedings be what Bruch (1979) called "inappropriate" (p. 56). An infant's cry is her most important tool to indicate needs and wants. The cry may be answered by the mother's response or lack thereof (neglect). A response might be appropriate, such as breastfeeding when the child's cry indicates hunger, or inappropriate such as ignoring the cries or forceful breastfeeding when the cry is actually a desire to be changed or held. Inappropriate responses by the mother can vary and every mother will misinterpret her child's cry at some point. This behaviour cycle can be applied to nearly every facet of an infant's life, but when it comes to eating, Bruch (1979) claimed that:

If ... a mother's reaction is continuously inappropriate, be it neglectful, oversolicitous, inhibiting, or indiscriminately permissive, the outcome for the child will be a perplexing confusion. When he is older he will not be able to discriminate between being hungry or sated, between nutritional need and some other discomfort or tension. At the extremes of eating disorders, one finds the grotesquely obese person who is haunted by the fear of starvation, and the emaciated anorexic who is oblivious to the pangs of hunger ... even more confusing to the child are the actions of a mother who is continuously preoccupied with herself. (p.56)

We cannot know the details of Sexton's breastfeeding relationship with her mother, but we do know that mother's milk and breasts were recurring themes throughout Sexton's oeuvre and that as children she and her sisters were desperate for her mother's attention. The word "breast" appeared 54 times and the word "milk" 39 times in Complete Poems. Lorand (1943) examined the role of mother's milk and breasts within anorexia and found, "What was once an oral desire for the breast and food, became a craving for all that could be taken in and eaten up, the mother's breast, everything the mother possessed, including the father" (p. 300). It was only through consuming her mother (not simply her breast milk) in the draft of "The Double Image" that Sexton succeeded in besting her. The draft reads: "I ate her summer into me and turned to swing / into my father's arm" (HRC Box 41.1). This is an act of reclamation with a generous dose of an Electra Complex, a disorder well associated with EDs. The poem's speaker exclusively eats the best part of her mother, peak season in full blossom, and in doing so finally earns the acceptance and love of her father. This feat is an example of what Sexton called "the great theme" of life (Sexton, 1977, p.26). According to Sexton (1977) in her early introductions to the poem, "The great theme is not Romeo and Juliet ... the great theme we all share is that of becoming ourselves, of overcoming our father and mother, of assuming our identities somehow" (p. 26).

\section{Role of Anorexia in the "The Double Image"}

The cannibalistic feast of her mother's "summer" ultimately fails to nourish her as she immediately begins to marvel at the contours of her bones. Ossip (2016) compares the bones to a bequest from Sexton's mother, which Sexton then passes on to her own daughter, Joyce. There are genetic components to EDs, which makes this bony inheritance a very fitting metaphor. The malnourishment is more overt in the draft version than the published version:

But my portrait, how thin

I was then; only the smile is slipping into place.

The shadow greens my bone; but only this gold in

The skin shapes me alive. The frozen eyes of my face

Disguise nothing. What could I have been thinking there,

To let them paint my sickness out? Perhaps I didn't care.

(HRC Box 41.1)

The closest echo of these lines to be found in published versions does not appear until later in the poem in part 6: "In north light, my smile is held in place, / the shadow marks my bone" (Sexton, 1960, p. 60). There is a focus on eating, thinness, bone, and skin in the draft - all correlations to an ED. Of course, Sexton was referring to her 1955 hospitalisation for attempted suicide and post-partum depression. However, these two diagnoses are not necessarily comprehensive and, as I believe, are sorely lacking. Cobb (1950) article, "Anorexia Nervosa as a Psychosomatic Problem," highlights just how advanced the understanding of anorexia was even during the time of Sexton's treatment, but (much like today) EDs often went undiagnosed or misdiagnosed ${ }^{2}$. 
If EDs were a part of Sexton's psychological disorders and presented in her creative work, as I believe, it is very unlikely that she would have received a complete and correct diagnosis in the 1950s when doing so is still such a challenge today. EDs are notorious for co-morbidities. Cobb (1950) found that many anorectic patients were "neurotically disturbed before they began their anorexia, and that all of them had bad relations with their parents" (p.142).

Sexton shared this common anorectic trait of having poor relationships with her parents. Her perceived shortcomings and craving for her parents' approval plagued Sexton throughout her life and helped to shape her into a young woman with a troubled sense of self or value. Her trusted therapist for over eight years, Martin Orne, said,

It is difficult to communicate fully how pervasive Anne's profound lack of self-worth was and how totally unable she was to think of any positive abilities or qualities within herself. When I pressed her to think hard about what she might be able to do [for a living], she finally revealed that there was only one thing that she might possibly be capable of doing well— to be a good prostitute and to help men feel sexually powerful. (as cited in Middlebrook,1991, p. xiii).

Middlebrook's account of Sexton's life was, of course, somewhat controversial as she was given unprecedented access to over 300 hours of therapy tapes between the poet and her therapist. However, this particular and professional input on Sexton's sense of self-worth came not from transcribed tapes but from the therapist himself.

\section{Sexton as a Confessional Poet}

Orne recalled that during one of their early sessions he asked Sexton, almost offhand, "How about writing?" as a means of expression, and once she started she could not stop (Middlebrook, 1991, p. xiv). It was through her poetry that she was empowered to explore the various facets of herself, her relationships, and what she called her illnessesthough it is clear when comparing the draft of "The Double Image" to published versions that even though she is one of the most famed confessional poets, she often took pains to veil and hide. Similar to other poets branded with the "confessional" label, for Sexton confessionalism was not strictly about disclosure and revelations but often equally about a sustained, artful, and deliberate form of obfuscation.

A great amount has been written regarding Sexton's confessional label, and she was oftentimes a part of this conversation. Sexton has said of A.R. Jones's claim that her work had an "unmistakably autobiographical impact" that she "would like for a moment to disagree" (HRC Crawshaw pp28). Sexton partially rebutted Jones's statement by replying, "It is true that I am an autobiographical poet most of the time, or at least so I lead my readers to believe" (HRC Crawshaw pp28). She told Marx in a 1965 interview for Hudson Review,

It's a very easy thing to say, "All poets lie." It depends on what you want to call the truth, you see, and it's also a way of getting out of the literal fact of a poem. You can say there is truth in this, but it might not be the truth of my experience. Then again, if you say that you lie, you can get away with telling the awful truth (p. 563-564).

Other times, Sexton would state that she wrote explicitly and honestly about herself, even claiming the title of confessional poet, such as when she asked rhetorically during a lecture at Colgate University, "How did I come to writing about myself? How did I come to be a confessional poet who vomits up her past every ugly detail onto the page?" (HRC Crawshaw pp.31). A draft introduction for the Poetry Book Society revealed "Many of them [the poems] are true. Others are about lives I haven't led" (HRC Crawshaw pp. 174). Sexton has written poems in firstperson in which she is clearly not being autobiographical, such as "For Johnny Pole on the Forgotten Beach" (1960) in which she makes up a brother. Gill (2007) pointed to these inconsistencies as an example of "possible confusion in her work between truth and lies, confession and invention, real and representative experiences" (p.78). Sexton has disclosed, "I like to lie. I like to confess. I like to hide" (HRC Crawshaw pp.171). There are many ways to do so, especially in poetry, such as slipping on a mask — or a coating of green paint.

\section{The Color Green in "The Double Image"}

When the speaker in the draft of "The Double Image" falls into her father's arms, the joy is short-lived. She quickly notices her thinness depicted in her portrait, how only her smile resembles her mother's, and how the shadows from her gauntness appear green. This greenness persists and is internalised in the published versions of the poem, reimagined as "ugly angels" and "green witches" in her head that remind her she is too old to be a child, "letting doom leak like a broken facet” (Sexton, 1960, p. 53). The Wizard of Oz was colourised in Technicolor when Sexton was 11 years old in 1939, which probably ensured that the image of a wicked green witch was burned into her memory (along with most of her peers). The cinematic version of the wicked witch was the first time witches were described with green skin. Traditionally, witches were most often depicted with red or orange skin if they differed in complexion from regular people at all. The wicked witch(es) in Baum's book series did not have green skin, and in fact there was no mention of witches with any unusual skin colour. The cinematic version of Baum's wicked witch sported green skin simply because it looked great in Technicolor, emphasised the suddenly hyper-colourful world Dorothy had landed in, and highlighted how otherworldly and scary the witch was. The film crew's choice of green skin worked marvellously and succeeded in giving children nightmares for decades ${ }^{3}$. 
It is impossible to know how familiar Sexton was with the $\mathrm{Oz}$ books and/or film, but her emphasis on cardinal directions in "The Double Image" is intriguing. She focused on north and south when describing the placement of the two portraits in the published versions of "The Double Image." These opposing directions were reserved for good witches in the world of Oz during Sexton's lifetime ${ }^{4}$. The most well-known "good witch" from the franchise is from the film version, Glinda, the Good Witch of the South. However, the original good witch first appeared in Frank L. Baum's The Wonderful Wizard of $\mathrm{Oz}(1900)$ as Locasta, the Good Witch of the North, who protected Dorothy with a kiss on the forehead - a mothering affection. Sexton carefully described the two portraits within the poem with convoluted language designed to misguide. A focus on portraits on the wall mirrors the days leading up to the hospitalisation discussed in the poem. Linda Sexton has said that post-partum depression led to her mother seeing "faces on the wall" and wanting to tear off the wallpaper - those faces might have looked a lot like hanging portraits (Sexton, 1994, p.16). Sexton was explicit in where her mother's portrait was initially hung in the poem, "placed on the south wall" (Sexton, 1960, p. 57). Later, that portrait was apparently moved to be "in south light" (Sexton, 1960, p. 60 ). A portrait hung on the south wall could not have southern light unless there was a well-situated skylight or other such trickery. When describing the placement of her own portrait, Sexton intentionally misleads the reader by mentioning "north" twice when (lighting logistics considered) she must have actually meant her portrait was hung on the south wall. She never specifies that her portrait is on the north wall—only in the north light. Consider these lines from parts 3 and 6 of the published poem:

They hung my portrait in the chill

north light, matching

me to keep me well.

Only my mother turned ill.

(Sexton, 1960, p. 56)

In north light, my smile is held in place,

the shadow marks my bone.

What could I have been dreaming as I sat there,

all of me waiting in the eyes, the zone.

(Sexton, 1960, p. 60)

A painting that is lit by northern light is almost certainly situated on the south wall. If this is the case, Sexton's portrait was always on the south wall while her mother's was also hung there initially, but somehow shifted to the north wall by the end of the poem. When was the mother's portrait moved from the south to north wall? Sexton's portrait was done first, which suggests that for a moment her mother's portrait was "placed on the south wall," superimposed upon (or, more suitably, coating) her daughter's. It is not until the end of part 5, after a stanza in which Sexton described a memory of playing in her mother's fur coat as a child, that her mother's portrait appears to have moved so that the "two portraits hang on opposite walls" (Sexton, 1960, p. 59). Consider the lines leading up to this statement:

That October day we went to Gloucester the red hills reminded me of the dry red fur fox coat I played in as a child; stock-still like a bear or a tent, like a great cave laughing or a red fur fox.

(Sexton, 1960, p.58)

It seems that for some time, Sexton's portrait was buried beneath her mother's much like she burrowed beneath her mother's coat as a child. The coat in the poem was, quite possibly, the same coat Sexton died in, a self-selected burial shroud of sorts that haunted her for years before her suicide. As Javadizadeh (2016) has pointed out, the coat is not really Sexton's mother's either but rightly belongs (or belonged) to the fox (p. 92). In the poem, it is not a coat the young speaker played in as a child but the animal itself (which she also likens to a bear). The line break between "fox" and "coat" emphasises this. These wild, predatory beasts are simultaneously caged when they are turned into a flashy wardrobe piece and also serve as a means of caging (and protecting) the young poem's speaker. The definition of "coat" itself has several meanings including the coats we wear to keep warm, an animal's outer layer of fur, and as a verb it can mean to cover or safeguard - all of which are applicable in this instance. The poem's speaker aligns herself squarely with the fox's snare in the first stanza of part 6, but only in the collected publication of the poem (not the Hudson publication). There are 29 modifications between the poem's version in Hudson Review and To Bedlam and Part Way Back, many of which are seemingly minor. However, between the two publications, the stanza depicting Sexton sitting for her portrait finds a single change that turns wonder into a declaration: 
What could I have been dreaming as I sat there,

all of me waiting in the eyes, the zone

of the smile, the young face,

the foxes' snare?

(Sexton, 1959, p. 77)

What could I have been dreaming as I sat there, all of me waiting in the eyes, the zone of the smile, the young face, the foxes' snare.

(Sexton, 1960, p. 60)

Grammatically, the sentence should end in a question mark, as it did in the Hudson publication. Instead, Sexton found it fitting to make a proclamation in the final collected version, though whether she is sitting in the foxes' snare or $i s$ the fox's snare herself is intentionally unclear. She is, perhaps, both, predator and prey-another double, complementary image.

Some, such as Javadizadeh (2016), have claimed that "The Double Image" includes lines that "do little to hide their autobiographical sources" by declaring dates ("I am thirty this November") and the fact that Sexton called it a "very personal poem" (p. 77). However, we have seen that with Sexton there is no such thing as reliable truths or concrete lies-she made that clear herself. Javadizadeh's (2016) literal reading of not only the poem but of Sexton's asides during her readings, which were ultimately performances, dismisses the artfulness of her craft and her mastery of suggestion. Sexton was very forthcoming about her role as performer, particularly when it came to reading her poems. She discussed her growing hatred of poetry readings in her article "The Freak Show" in which she claimed that with readings poets write for the audience and the poet is simply an entertainer: "You are the freak. You are the actor, the clown, the oddball" (Sexton, 1973, p.38). One year later, Sexton wrote to Erica Jong in June 1974 after Jong attended one of Sexton's readings to make sure she knew, "that isn't the real me, the woman of the poems, the woman of the kitchen, the woman of the private (but published) hungers" (Sexton, 1977, p. 371). Even before the accolades, fame, and public scrutiny, when Sexton was writing her earliest poems like "The Double Image," she knew that every word mattered. When a poem is written to sit in text form, not performed, the reader can mull over each word choice with relish. These choices included her decision to use only "good" locations for the portraits throughout "The Double Image."

\section{Conclusion}

The north and south portrait locations may have been an attempt to erase the green wickedness from her inner "ugly angel." This was not the first time Sexton aligned herself with a witch—or was thought as such by others. The word "witch" appears 33 times in Complete Poems, including in "The Witch's Life" (Sexton, 1975). The opening poem in Transformations, "Gold Key," begins with the lines "The speaker in this case / is a middle-aged witch, - me" (Sexton, 1971, 1). The witch is central to what Middlebrook dubbed Sexton's signature poem, "Her Kind" (1960), which was Sexton's usual opening poem at readings (xix). "Her Kind" shares the imagery of a cave with "The Double Image," and in it Sexton famously and boldly declared, "I have been her kind" (Sexton, 1960, p. 21). Paul Brooks wrote to Sexton after hearing her perform the poem in 1968, saying, "As you well know, you are something of an enchantress." (Middlebrook, 1991, p. 305). Her answer was an admission: "What can I say in reply? Tell you that of course I am a witch, an enchantress of sorts and have already been worshipped and hung in the same order" (Sexton, 1977, p. 292). She was, as Conway (2016) has claimed, "completely at peace with her witchy-ness and demons" (p. 214). In 1975, Sexton collaborated with Maxine Kumin to write the children's book The Wizard's Tears, which continues her possible appreciation of the $\mathrm{Oz}$ franchise well beyond the Bedlam years. No witches are present in the story, but the wizard does turn the townspeople an array of green shades. Gill attributed Sexton's "The Red Shoes" (1972) to the film of the same name, but it is impossible to not also think of the glittering red shoes from Oz ("Reading Place" 28). When considered alongside the world of Oz, the speaker of "The Red Shoes" aligns herself with a long lineage of witches:

They are not mine.

They are my mother's.

Her mother's before.

Handed down like an heirloom

but hidden like shameful letters.

(Sexton, 1972, p.28) 
Perhaps the most impressive witchery within Sexton's poetry is her ability to encourage the reader to conjure up their own imagery - she did say, after all, she was ultimately "writing for one person, that one perfect reader who understands and loves" (Sexton, 1973, p. 38). How you picture the portraits in "The Double Image" is different than anyone else. Bachelard (2014) has said that "at the very first poetic overture, the reader who is 'reading a room' leaves off reading and starts to think of some place in his own past" (p. 35). I personally envision the portraits in a brightly lit, airy open room with light beige walls. A photographic rendering of the two portraits in unpublished Ted Polumbaum prints for Look magazine arrange them in a dim attic surrounded by cardboard boxes (Helle, 2016, p. 59). By allowing the reader's imagination to take over, which it would to some degree anyway, Sexton welcomes us into her poetry, world, and personal history including, perhaps, anorexia as part of her mental disorder makeup. Poetry very well can (and should) stand on its own two feet. However, when considering the creative process and the intricate ways a person's complex being influences and informs their work, it is impossible to untether the anorectic poet from what is ultimately an anorectic work - at least to some degree.

\section{References}

Bachelard, G. (2014). The Poetics of Space. Penguin.

Beaumont, J. M. (2016). The Speaker in This Case: Anne Sexton at Tale-Teller in Transformations. This Business of Words: Reassessing Anne Sexton. (A. Golden, Ed.) UP of Florida.

Bruch, H. (1979). Eating Disorders: Obesity, Anorexia Nervosa, and the Person Within. Basic Books.

Cobb, S. (1950). Emotions and Clinical Medicine. WW Norton \& Co Inc.

Colburn, S. (1988). Anne Sexton: Telling the Tale. University of Michigan Press.

Conway, J. (2016). Coming to Terms with Anne Sexton's Late Poetics and Public Persona. This Business of Words: Reassessing Anne Sexton. (A. Golden, Ed.) UP Florida.

Dorfman, E. (1981). Portrait of the Portrait Photographer. The Journal of New England Photography, 2, Winter, 1-14. Furst, A. (2000). Anne Sexton: The Last Summer. St. Martin's.

Gill, J. (2007). Anne Sexton's Confessional Poetics. UP Florida.

Gill, J. (2016). Reading Place and Space in the Poetry of Anne Sexton. This Business of Words: Reassessing Anne Sexton. UP Florida.

Gull, W. (1873). Anorexia Nervosa (Apepsia Hysterica, Anorexia Hysterica). Obesity Research, 5 (1), 498 - 502.

Hedley, J. (2000). I Made You to Find Me: Sexton, Lowell, and the Gender of Parenthood. Raritan, 19 (3), $87-114$.

Helle, A. (2016). Anne Sexton's Photographic Self-Fashioning. This Business of Words: Reassessing Anne Sexton. (A. Golden, Ed.) UP Florida.

Holdstein, D \& Bleich, D. (2001). Personal Effects: The Social Character of Scholarly Writing. All USU P Publications.

Jack, R. (1986). Anorexia, Allergy or Arsenic? British Homeopathic Journal, 72 (1), 28 - 36.

Javadizadeh, K. (2016). Anne Sexton's Institutional Voice. This Business of Words: Reassessing Anne Sexton. UP Florida.

LeRoy, M. (Producer), \& Fleming, V. (Director). (1939). The Wizard of Oz [Motion Picture]. United States: MetroGoldwyn-Mayer.

Lacan, J. (1977). Écrits: A Selection. Translated by Alan Sheridan. Tavsistock/Routledge.

Lorand, S. (1964). Anorexia Nervosa: Report of a Case. Evolution of Psychosomatic Concepts: Anorexia Nervosa, a Paradigm. (M. Kaufman \& Marcel Heiman, Ed.). International UP.

Marx, P. (1965-1966). Interview with Anne Sexton. Hudson Review, 18, 560-570.

Meyer, B. \& Weinroth, L. (1957). Observations on Psychological Aspects of Anorexia Nervosa. Psychosomatic Medicine, 19(5), 389-398.

Middlebrook, D. W. (1991). Anne Sexton: A biography. Houghton Mifflin.

Ostriker, A. (1998). That Story: The Changes of Anne Sexton. Writing Like a Woman, U of Michigan P.

Ossip, K. (2016). Are We fake? Images of Anne Sexton, Twentieth-Century Woman/Poet. This Business of Words: Reassessing Anne Sexton. (A. Golden, Ed.) UP of Florida.

Raineri, K. (2014). Treatment for Eating Disorders with Emphasis on Risk Factors and Special Consideration for Minorities. Master's thesis, Pacific University.

Rigl, A. (2014). The Anorexic Aesthetic: An Analysis of Poetics of Gluck, Dickinson, and Bidart. Master's thesis, Vanderbilt University.

Ressler, A. (1998). A Body to Die For: eating disorders and body-image distortion of women. International Journal of Fertility and Women's Medicine, 43(3), 133-138.

Segal, H. (2018). Introduction to the Work of Melanie Klein. Routledge.

Sexton, A. (2020, May). Anne Sexton Papers. The Harry Ransom Center, The University of Texas at Austin.

Sexton, A. (1975). The Awful Rowing Toward God. Houghton Mifflin.

Sexton, A. (1972). The Book of Folly. Houghton Mifflin.

Sexton, A. (1991). The Complete Poems. (L. Gray Sexton \& L. Conant Jr, Ed.). First Mariner Books. 
Sexton, A. (1959). The Double Image. Hudson Review, 12(1), 73-79.

Sexton, A. (1977). A Self-Portrait in Letters. (L. Gray Sexton \& L. Ames), Houghton Mifflin.

Sexton, A. (1960). To Bedlam and Part Way Back. Houghton Mifflin.

Sexton, A. (1972). The Book of Folly. Houghton Mifflin.

Sexton, A. (1973). The Freak Show. American Poetry Review, 2(3), 38 - 40.

Sexton, A. (1971). Transformations. Houghton Mifflin.

Sexton, L. (1994) Searching for Mercy Street. Counterpoint.

Van Hyning, V. (2016). Reading, Voice, and Performance: 'The Freak Show' Revisited. This Business of Words: Reassessing Anne Sexton. (A. Golden Ed.) UP Florida.

Williamson, A. (1983). Confession and Tragedy. Poetry, 5(142), 170 -178.

\section{Endnotes}

\footnotetext{
${ }^{1}$ One reference describing the relationship between cold sweats and anorexia is R.A.F. Jack's "Anorexia, allergy or arsenic?"

${ }^{2}$ In 1998, anorexia and bulimia were described as having reached "epidemic proportions" in the United States but often remained undiagnosed (Ressler 133).

${ }^{3} \mathrm{Oz}$ 's wicked witch made an appearance on Sesame Street nearly 40 years later in 1976, which led to multiple letters from angry parents claiming the episode terrified their children.

${ }^{4}$ There is a wicked witch of the south in the $O z$ franchise, Singra. Rachel Cosgroves Payes wrote The Wicked Witch of $O z$ featuring Singra in the 1950s, but it was not published until 1993 and well after Sexton's death.
} 